
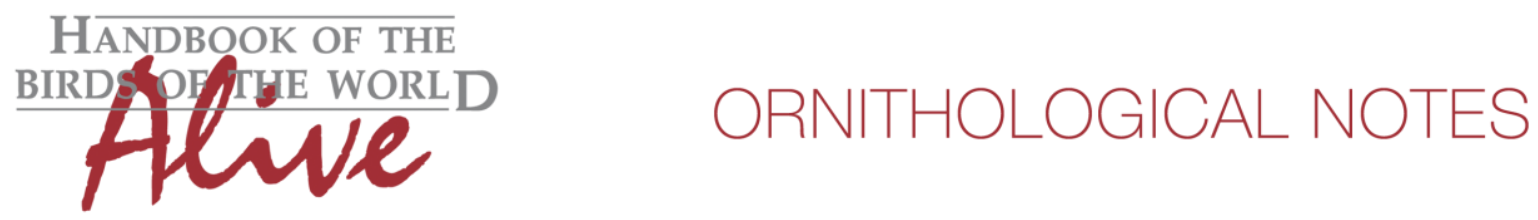

\title{
Notes on the vocalizations of Yellow-green Tyrannulet (Phylloscartes flavovirens) and Olive-green Tyrannulet (Phylloscartes virescens)
}

\author{
Peter Boesman
}

In the following we briefly analyze and compare voice of Yellow-green Tyrannulet (Phylloscartes flavovirens) and Olive-green Tyrannulet (Phylloscartes virescens). We also try to quantify the extent of any vocal differences using the criteria proposed by Tobias et al. (2010), as a support for taxonomic review.

We have made use of sound recordings available on-line from Xeno Canto (XC) and Macaulay Library (ML).

Song of these two closely related Tyrannulets is poorly documented, with only recently more recordings of $P$. virescens becoming available, while Yellow-green Tyrannulet (despite occurring in the city park of Panama City !) still needs much better documentation of voice. Only a quick comparison is needed to conclude song of both species is quite different:

P. virescens $(n=8)$

Song is a phrase of some 8-10 well-spaced short notes, the first 2-3 quite crisp, the subsequent ones monotonous staccato "twink!..twink!..tsik..tsik..tsik..tsik...tsik" (Fig. 1).

$\begin{array}{ll}\text { Length } & 2.13-4.6 \mathrm{~s} \\ \text { \# of notes } & 7-10 \\ \text { pace } & 0.30-0.48 \\ \text { max. freq. } & 4830-5840 \mathrm{~Hz} \\ \text { low max. freq. } & 2690-3800 \mathrm{~Hz}\end{array}$

P. flavovirens ( $n=3)$

Presumed song is a variable number of short fairly-high-pitched trills "trri...trrri...trr" or alternatively a single trill followed by a buzzy note (?) (Fig. 1).

$\begin{array}{ll}\text { Length } & 0.13-1.6 \mathrm{~s} \\ \text { \# of notes } & 3-14 \text { (in bursts of 3-7 notes) } \\ \text { pace } & 0.04-0.055 \\ \text { max. freq. } & 3730-4000 \mathrm{~Hz} \\ \text { low max. freq. } & 2400-2500 \mathrm{~Hz}\end{array}$

*: max. freq. of fundamental, which in case of flavovirens can be very weak in amplitude.

P. virescens differs in basic parameters such as e.g. total song length (score 2), pace (score 4), max. frequency (score 2 ) etc. 

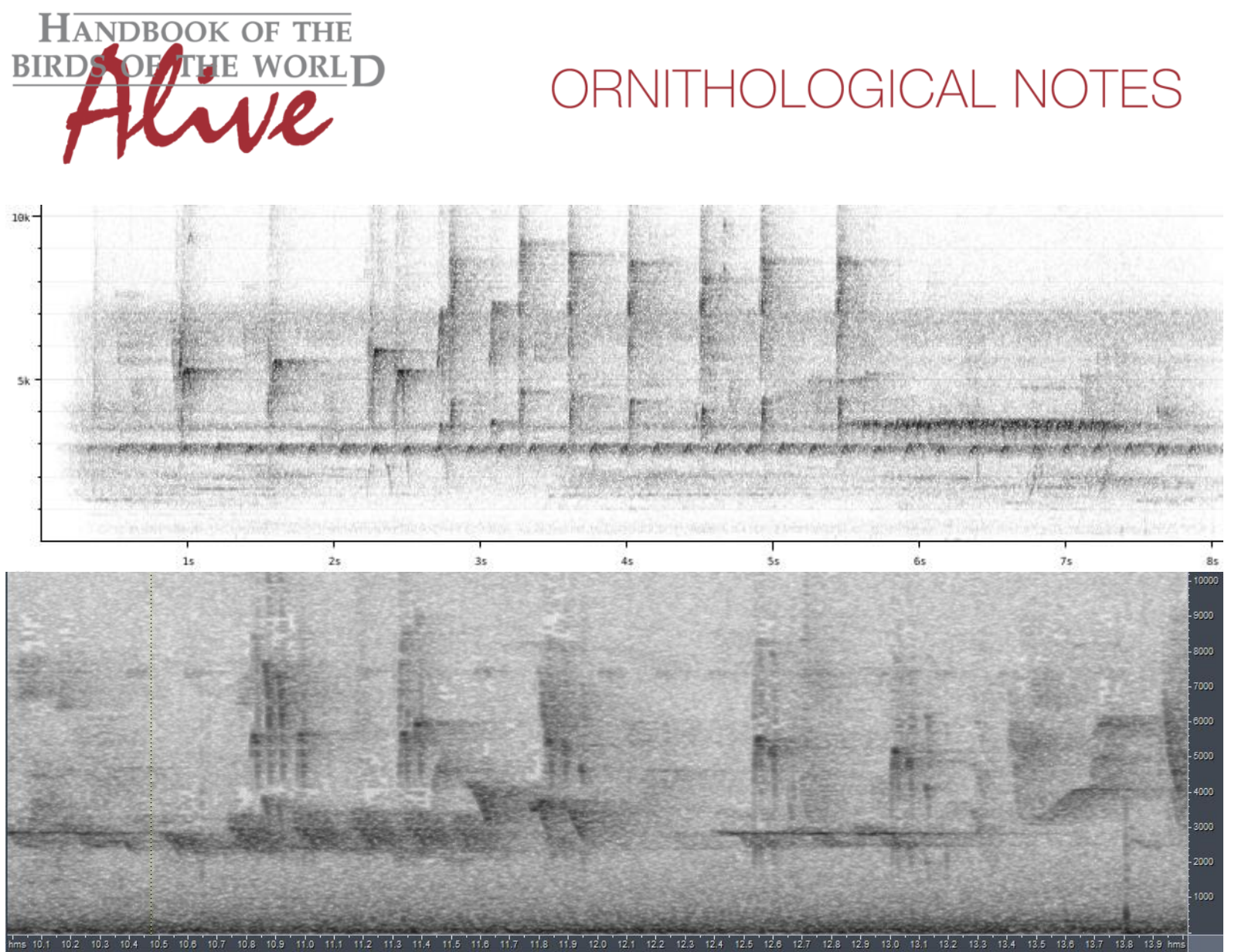

Figure 1: typical song of virescens (top) and on a very different time scale flavovirens (bottom)

This note was finalized on 29th June 2015, using sound recordings available on-line at that moment. We would like to thank in particular the sound recordists who placed their recordings for this species on XC and ML: Nick Athanas, Peter Boesman, Olivier Claessens, Alex Lees, Gabriel Leite, Linda Macaulay, Ted Parker and Alexandre Renaudier.

\section{References}

Tobias, J.A., Seddon, N., Spottiswoode, C.N., Pilgrim, J.D., Fishpool, L.D.C. \& Collar, N.J. (2010). Quantitative criteria for species delimitation. Ibis 152(4): 724-746.

\section{Recommended citation}

Boesman, P. (2016). Notes on the vocalizations of Yellow-green Tyrannulet (Phylloscartes flavovirens) and Olive-green Tyrannulet (Phylloscartes virescens). HBW Alive Ornithological Note 116. In: Handbook of the Birds of the World Alive. Lynx Edicions, Barcelona. (retrieved from http://www.hbw.com/node/932021 on 4 August 2016). 